\title{
SULFUR OXIDATION IN INOCULATED AND UNINOCULATED GREENSAND MIXTURES AND ITS RELATION TO THE AVAILABILITY OF POTASSIUM ${ }^{1}$
}

\author{
W. RUDOLFS \\ New Jersey Agricultural Experiment Stations \\ Received for publication October 18, 1921
}

Although a study of the literature shows that the application of greensand for agricultural purposes has proved beneficial, and although good results from the use of greensand were recognised long ago in England and France and later in America, especially in New Jersey, farmers did not turn to these great resources even during the war-time scarcity of potassium. This is undoubtedly due to the fact that all greensands found in America have but a low percentage of potassium and to the ease with which the farmer in ordinary times can buy readily available potash.

The potassium of the greensand is but slowly available for plant food and the addition of greensand to a soil serves mainly the future crops. For building up a soil, poor in potassium, it has proven to be a great asset. The value of greensand as a fertilizer has been, and is still often ascribed to the calcium carbonate and phosphorus present. Since a large number of the New Jersey greensands contain from 1 to 3 per cent phosphoric acid and from 3 to 7 per cent potassium, it is probable that the immediately beneficial effects can be attributed to both these constituents. In many cases not much calcium carbonate is present and the greensand dug often has a decided acid reaction. The greensands and greensand marls found in England often contain as much as from 8 to 10 per cent of $\mathrm{K}_{2} \mathrm{O}$, but usually little or no phosphoric acid.

\section{REVIEW OF LITERATURE}

The war stimulated the study of practical methods for rendering the potassium soluble Experiments were conducted in several states upon the availability of greensands for plant food, and upon the possibilities of securing means to treat the greensand. The Eastern Potash Corporation in New Jersey (13) claims to have found a factory method which consists of treating the greensand with lime and steam under pressure, for which process a plant is under construction.

\footnotetext{
I Paper No. 92 of the Journal series New Jersey Agricultural Experiment Stations, Department of Soil Chemistry and Bacteriology. This paper will appear in RuTGers Counege STubIes, vol. 1.

2 Part of a thesis submitted to the faculty of Rutgers College and the State University of New Jersey in partial fulfillment for the requirements of the degree of doctor of philosophy. The writer wishes to express his thanks to Dr. J. G. Lipman for the suggestion of this problem and for the interest taken in the progress of the work.
} 
Ashley (2) deems it entirely feasible to concentrate the glauconite by electric magnets, while his experiments with a solution of carbon di-oxide, sulfur di-oxide and dilute hydrochloric acid failed to give results of value for the production of commercial potash. A recently reported study at the Maryland Agriculture Experiment Station (9) shows the possibility of composting greensand with inoculated sulfur and manure as a practical means for farmers to make use of the potassium in the greensand.

A number of experiments have been conducted in different European countries with local greensand marls. In America the value of greensand has long been known. .In 1819, at least four-fifths of the land in New Jersey around the places where the greensand marl is found, or two-fifths of the whole state was barren according to Morse's American Universal Geography (10). The analyses of the greensand made by Seybert (12) in 1822 shows the existing interest in these early days. A few years later Gordon (6, part 2, p. 5) wrote "It would be difficult to calculate the advantages which the state has gained, and will yet derive from the use of marl. It has already saved some districts from depopulation and increased the inhabitants of others, and may one day contribute to convert the sandy, and pine deserts into regions of agricultural wealth." The prediction of Gordon has come true and much of the land he considered as "deserts" are at present "regions of agricultural wealth." Cook (5) published in 1868 a geological report giving a large number of analyses of greensand samples. In his discussion he ascribes the heavy crops of clover, etc., to the beneficial effects of greensand partly because of the phosphoric acid content and partly because of the sulfuric acid found in it, for "this (sulfuric acid) constituent combines with lime forming plaster" of which the "efficiency as a fertilizer is well known, though the cause of its action is not satisfactorily explained." Although at that time the part played by potassium was not well understood, Cook points out that the peculiarly beneficial effects of greensand on potatoes containing high amounts of potassium, has strengthened the opinion that this constituent of the marl is of high value.

The most interesting greensand deposits of New Jersey and Maryland have been described by a number of writers. Clark (4), Ashley (2, p. 27-58) and others comment similarly on the value of greensand as a fertilizer. Patterson (11) concludes that the marls of Maryland have very little value for commercial extraction of the potassium on account of the great mass of worthless material in these shell marls. Blair (3) while reporting a number of analyses of New Jersey greensand samples concludes that, under the conditions existing in the soil, the potash of the greensand marls becomes gradually available, and since "potash is of especial value to potatoes and to grasses, the benefits derived from marl when used for these crops would lead one to believe that such crops can use the potash of marl to a considerable extent." Lipman and Blair (7) conducted experiments in pots with coarse sand growing barley and buckwheat followed by a crop of soy beans, using greensand as a source of potassium. Barley and buckwheat gave greatly increased yields over the check pots in these experiments. Soy beans fertilized with greensand produced as great a yield of hay as those receiving an application of soluble potassium salts. True and Geise (14) made a study of potassium salts and greensands in sand cultures, using Shive's complete nutrient solution, $R_{6} C_{2}$, as a basis. They conclude that "greensand and greensand marls from Virginia and New Jersey are able to supply sufficient potassium to satisfy the demands of Turkey Red wheat and red clover during the first two months of their growth. This enables them to make a greater dry weight of tops than was seen in similar cultures in which the potassium demand was supplied by potassium chloride, potassium sulfate, and potassium phosphate." Lipman and his co-workers (8) report field experiments with mixtures of greensand marl and inoculated sulfus. The greensand was applied together with acid phosphate and dried blood. The yields obtained with inoculated sulfur alone were as great as the returns from plots receiving a combination of greensand and inoculated sulfur, but the greensand alone compared with the uninoculated sulfur gave slightly greater yields, but the air dry weights produced by a combination of uninoculated sulfur and greensand was lower than the yields produced by either greensand or sulfur alone or a combination of these two constituents. 
Ames and Boltz (1) report to have found that the oxidation of sulfur in the soil as well as dried blood liberated potassium. From these studies they conclude that the liberation of potassium was brought about by the salts rather than by the direct action of acidity on the insoluble potassium compounds. McCall and Smith (9) composted greensand with sulfur, soil and manure for the purpose of determining the effect of different composts upon the availability of the potassium of greensand. They inoculated the mixtures with a soil extract known to contain sulfur-oxidixing organisms and concluded, after an incubation period of 23 weeks, that "in composts consisting of greensand, manure, and soil in different proportions, an appreciable amount of potassium of the greensand was made water-soluble." Composts which yielded the largest quantities of water-soluble potassium contained the largest proportions of manure, indicating that nitrogen stimulates sulfur oridizing bacterial activities.

\section{PLAN OF EXPERTMENT}

The experiments reported below were conducted primarily for the purpose of determining the effect of uninoculated sulfur as compared with inoculated sulfur upon the availability of potassium. In the second place the object was to study the possibility of decreasing the large quantities of soil used in earlier experiments, so as to make composting of greensand with sulfur more practical for the farmer or manufacturer, and in the third place to determine the effect of ammonium sulfate upon the rapidity with which the potassium ingreens and becomes available when no soil is used in the mixtures.

The experiments consisted of composting greensand with sulfur and soil in varying proportions and with additions of ammonium sulfate. Commercial sulfur and Penn loam were used. The greensand was from Eatontown, N. J., with a fairly high percentage of potassium and but a trace of calcium. Half of the mixtures were inoculated with infusions known to contain sulfuroxidizing organisms, and to the other half no sulfur-oxidizing organisms were added. It was found extremely difficult to keep the uninoculated mixtures free from contamination. Although sterilized sulfur was used, much, if not all, of the soil around the New Jersey Experiment Station contains the sulfur-oxidizing organisms. The soil was left unsterilized so as not to change the soil flora, which would have resulted in placing some of the cultures at a too great disadvantage.

The materials were mixed in the following proportions:

\begin{tabular}{|c|c|c|c|c|}
\hline $\begin{array}{l}\text { COMPOST } \\
\text { NUMBER }\end{array}$ & PARTS OI SOIL & $\begin{array}{c}\text { PARTS } \\
\text { Of SULYUTR }\end{array}$ & $\begin{array}{c}\text { PARTS } \\
\text { OY GREENSAND }\end{array}$ & \\
\hline $\begin{array}{l}1 \text { and } 9 \\
2 \text { and } 10 \\
3 \text { and } 11 \\
4 \text { and } 12 \\
5 \text { and } 13 \\
6 \text { and } 14 \\
7 \text { and } 15 \\
8 \text { and } 16 \\
9 \text { and } 18\end{array}$ & $\begin{array}{r}100 \\
100 \\
20 \\
20 \\
0 \\
0 \\
0 \\
0 \\
0\end{array}$ & $\begin{array}{r}20 \\
40 \\
20 \\
40 \\
20 \\
40 \\
20 \\
40 \\
0\end{array}$ & $\begin{array}{r}80 \\
60 \\
160 \\
140 \\
180 \\
160 \\
180 \\
160 \\
200\end{array}$ & $\begin{array}{l}0.2 \text { per cent }\left(\mathrm{NH}_{4}\right)_{2} \mathrm{SO}_{4} \text { added } \\
0.2 \text { per cent }\left(\mathrm{NH}_{4}\right)_{2} \mathrm{SO}_{4} \text { added }\end{array}$ \\
\hline
\end{tabular}




\section{METHODS}

All materials were air-dry and mixed thoroughly before the inoculations were made and before the ammonium sulfate was added. A part of each mixture was used for determining the water-holding capacity, Hilgard method. Water equivalent to 60 per cent of the water-holding capacity was then added to the mixtures and they were left standing over night before determinations of hydrogen-ion concentration, relative acidity, sulfates and potassium were made. The cultures were placed in tumblers covered with glassplates and incubated at $28^{\circ} \mathrm{C}$.

Water extractions were made of weighed air-dried samples from each compost by shaking $20 \mathrm{gm}$. of mixture with $200 \mathrm{cc}$. of distilled water in 1-liter flasks in a shaking machine for 2 hours. The flasks were left standing over night and an aliquot drawn off from each for the $\mathrm{pH}$ determinations. The remainder of the contents of the flasks was then filtered until the liquid was clear.

The hydrogen-ion concentrations were at first determined according to the method described by Gillespie and later checked up with a portion of the liquid drawn off after shaking of the mixture with distilled water. The differences,

TABLE 1

Composition of greensand and soil used

\begin{tabular}{|c|c|c|c|c|c|c|c|c|}
\hline & $\begin{array}{l}\text { MOIS- } \\
\text { TUREE }\end{array}$ & $\begin{array}{l}\text { INSOLU- } \\
\text { BLE } \\
\text { RESIDUE }\end{array}$ & $\begin{array}{l}\mathrm{Fe}_{2} \mathrm{O}_{2} \\
\mathrm{Al}_{2} \mathrm{O}_{2} \\
\mathrm{MgO} \\
\mathrm{Na} \mathrm{O}\end{array}$ & $\mathrm{K}_{2} \mathrm{O}$ & $\mathrm{P}_{2} \mathrm{O}_{6}$ & $\mathrm{CaO}$ & so, & pH \\
\hline & per cent & per cent & per cent & Der cent & percent & per cent & per cent & per cent \\
\hline Greensand. . & 3.54 & 54.11 & 30.79 & 4.53 & 1.16 & Trace & 1.08 & 6.5 \\
\hline Penn loam......... & 2.17 & 76.04 & 12.49 & 0.49 & 0.17 & 0.32 & 0.52 & 6.7 \\
\hline
\end{tabular}

if any, were always very slight. As indicators, the series recommended by Clark and Lubs was used with the apparatus described by Van Alstine (15).

Determinations of relative acidity were made upon aliquots of the water extract. The liquid was boiled to expel carbon dioxide, cooled, and titrated with $0.1 \mathrm{~N} \mathrm{NaOH}$, using phenolphthalein as an indicator.

Potassium determinations were made gravimetrically at the platanic chloride method from aliquots of the water extract. The silicates, iron, aluminum, phosphorus and soluble organic matter were eliminated by evaporation with $\mathrm{H}_{2} \mathrm{SO}_{4}$, ignition and subsequent precipitation with $\mathrm{NH}_{4} \mathrm{OH}$.

The soluble sulfur was determined by acidifying aliquots of the water extract with concentrated hydrochloric acid and precipitating at the boiling point with barium chloride. The results are calculated as sulfur trioxide $\left(\mathrm{SO}_{3}\right)$.

The results recorded are calculated on the moisture-free basis of the soil and greensand. Moisture determinations being made by heating portions of air-dry material and composts for 15 hours at $105^{\circ}$ to $108^{\circ} \mathrm{C}$.

The greensand and soil were analysed by the official methods at the beginning of the investigation. The results are reported in table 1. 
From the hydrogen-ion concentration determinations it may be seen that both soil and greensand were slightly acid. The greensand was rather coarse and therefore crushed in a mortar before mixing with the soil. Mechanical analyses of the greensand and Penn loam used, showing their texture, are given in table 2.

TABLE 2

Mechanical analyses of greensand and soil used

\begin{tabular}{|c|c|c|}
\hline constants & GRERNSAND & PENN LOAY \\
\hline & per cent & per cont \\
\hline Fine gravel $\ldots \ldots \ldots \ldots \ldots \ldots \ldots \ldots \ldots \ldots \ldots \ldots$ & 0.42 & 6.75 \\
\hline Coarse sand $\ldots \ldots \ldots \ldots \ldots \ldots \ldots \ldots \ldots \ldots \ldots \ldots$ & 18.64 & 23.92 \\
\hline Fine sand $\ldots \ldots \ldots \ldots \ldots \ldots \ldots \ldots \ldots \ldots \ldots \ldots \ldots \ldots \ldots \ldots$ & 42.75 & 26.25 \\
\hline Very fine sand $\ldots \ldots \ldots \ldots \ldots \ldots \ldots \ldots \ldots \ldots \ldots$ & 29.20 & 26.56 \\
\hline Silt and clay $\ldots \ldots \ldots \ldots \ldots \ldots \ldots \ldots \ldots \ldots \ldots$ & 8.63 & 16.32 \\
\hline
\end{tabular}

EXPERIMENTAL RESULTS

Acidity and hydrogen-ion concentration

The acidity and hydrogen-ion concentration of the water extracts from each compost were determined at intervals of the inoculated and the uninoculated mixtures. Part of the data obtained are reported in table 3.

It is clear from the data presented that no great differences were found between the cultures with inoculated and uninoculated sulfur. As has been pointed out this was to be expected since it is extremely difficult to keep the inoculated mixtures from contamination under ordinary laboratory conditions. All cultures showed a rapid change in hydrogen-ion concentration and a gradual increase in titratable acidity. After 6 weeks one of the cultures to which soil was added had reached the point of hydrogen-ion concentration at which the potassium of the greensand becomes available, which point was reached by most of the cultures after an incubation period of 9 weeks. From then on the hydrogen-ion concentration changed but slightly, although acidity accumulation went on, showing that sulfur oxidation proceeded. These slight changes in hydrogen-ion concentration indicate that but relatively small amounts of free acid existed and nearly all of the acidity titrated existed in the form of sulfates. The mixtures with soil made somewhat larger quantities of acidity, from the beginning but the intensity of the acid produced was generally less than in the cultures without soil. The quantities of acidity titrated were highest in the mixtures with 50 per cent soil. Addition of ammonium sulfate did not seem to have much influence upon the quantity of acid produced, nor upon the intensity of the acid produced except, possibly, as shown by some slight differences in the uninoculated cultures between those receiving neither soil nor ammonium sulfate and those receiving ammonium sulfate but without soil. There seemed to be sufficient nitrogen available for the needs of the organisms to last until the end of the experiment. 
TABLE 3

Accumulation of water-soluble acidity, hydrogen-ion concentration, water-soluble sulfate, and water-soluble in potassium inoculated and uninoculated compost mixtures

\begin{tabular}{|c|c|c|c|c|c|c|c|c|c|c|c|c|c|}
\hline \multirow{2}{*}{ soncour } & \multicolumn{3}{|c|}{ COMPOSITION } & \multirow{2}{*}{\multicolumn{2}{|c|}{$\begin{array}{c}\text { DNTruar } \\
\text { REACTION }\end{array}$}} & \multirow{2}{*}{\multicolumn{2}{|c|}{$\begin{array}{l}\text { REACTiON } \\
\text { ATrkR } \\
18 \text { WELES }\end{array}$}} & \multicolumn{4}{|c|}{ SO, PER 10 ar. OI COMPOST } & \multicolumn{2}{|c|}{$\begin{array}{l}\text { K PER } 10 \mathrm{GM} . \\
\text { OP COKCPOST }\end{array}$} \\
\hline & Soil & $\begin{array}{l}\text { Sul- } \\
\text { fur }\end{array}$ & $\begin{array}{l}\text { Green- } \\
\text { sand }\end{array}$ & & & & & $\underset{\text { start }}{\text { At }}$ & \begin{tabular}{c|} 
After \\
9 \\
weeks
\end{tabular} & $\begin{array}{c}\text { After } \\
15 \\
\text { weeks }\end{array}$ & $\begin{array}{c}\text { After } \\
18 \\
\text { weeks }\end{array}$ & $\underset{\text { start }}{\text { At }}$ & $\begin{array}{c}\text { After } \\
18 \\
\text { weeks }\end{array}$ \\
\hline \multicolumn{14}{|c|}{ Inoculated } \\
\hline & | parts & parts & paris & $c c$. & $p H$ & $c_{c .}^{*}$ & $p H$ & mgm. & $m g m$. & $m g m$. & $m g m$. & $m g m$. & mgrm. \\
\hline 1 & 100 & 20 & 80 & 0.05 & 6.6 & 37.6 & 2.3 & 1.32 & 200.24 & 218.99 & 233.08 & 1.24 & 7.91 \\
\hline 2 & 100 & 40 & 60 & 0.05 & 6.6 & 42.0 & 2.2 & 1.30 & 186.74 & 211.25 & 228.66 & 1.08 & 7.39 \\
\hline 3 & 20 & 20 & 160 & 0.05 & 6.6 & 26.8 & 2.2 & 1.48 & 158.22 & 184.96 & 200.85 & 0.72 & 11.79 \\
\hline 4 & 20 & 40 & 140 & 0.05 & 6.6 & 31.2 & 2.0 & 1.48 & 184.99 & 204.89 & 206.92 & 0.56 & 12.68 \\
\hline 5 & 0 & 20 & 180 & 0.06 & 6.6 & 29.6 & 2.0 & 1.70 & 161.16 & 207.47 & 212.07 & 0.62 & 16.48 \\
\hline 6 & 0 & 40 & 160 & 0.08 & 6.6 & 25.8 & 2.0 & 1.68 & 114.58 & 164.81 & 184.47 & 0.53 & 11.47 \\
\hline 7 & $0 \dagger$ & 20 & 180 & 0.10 & 6.6 & 24.0 & 2.1 & 3.72 & 147.50 & 184.60 & 198.89 & 0.36 & 12.71 \\
\hline 8 & $0+$ & 40 & 160 & 0.08 & 6.6 & 30.0 & 2.0 & 3.40 & 150.18 & 193.92 & 215.27 & 0.20 & 11.71 \\
\hline 17 & 0 & $\mathbf{0}$ & 200 & 0.10 & 6.5 & 0.1 & 6.3 & 1.08 & 6.60 & 7.90 & 8.02 & 0.25 & 0.29 \\
\hline \multicolumn{14}{|c|}{ Uninoculated } \\
\hline 9 & 100 & 20 & 80 & 0.05 & 6.6 & 31.2 & 2.2 & 1.32 & 101.66 & 145 & 197.86 & 0.54 & 7.23 \\
\hline 10 & 100 & 40 & 60 & 0.05 & 6.6 & 38.2 & 2.4 & 1.30 & 163.74 & 192.35 & 218.15 & 0.82 & 6.07 \\
\hline 11 & 20 & 20 & 160 & 0.05 & 6.6 & 24.2 & 2.1 & 1.48 & 146.92 & 161.99 & 179.14 & 0.27 & 11.07 \\
\hline 12 & 20 & 40 & 140 & 0.05 & 6.6 & 31.4 & 2.1 & 1.48 & 173.01 & $\mid 184.43$ & 199.92 & 0.45 & 11.31 \\
\hline 13 & 0 & 20 & 180 & 0.06 & 6.6 & 19.3 & 2.3 & 1.70 & 101.02 & 141.54 & 170.77 & 0.15 & 12.27 \\
\hline 14 & 0 & 40 & 160 & 0.08 & 6.6 & 17.2 & 2.3 & 1.68 & 113.85 & 159.17 & 149.55 & 0.27 & 11.31 \\
\hline 15 & $0+$ & 20 & 180 & 0.09 & 6.6 & 27.0 & 2.2 & 3.72 & 142.19 & 158.52 & 192.40 & 0.18 & 13.80 \\
\hline 16 & $0+$ & 40 & 160 & 0.08 & 6.6 & 22.8 & 2.3 & 3.40 & 130.95 & 182.62 & 190.86 & 0.18 & 12.18 \\
\hline 18 & 0 & 0 & 200 & 0.10 & 6.5 & 0.1 & 6.2 & 1.08 & 6.58 & 7.22 & 8.83 & 0.25 & 0.36 \\
\hline
\end{tabular}

* Acidity expressed in cc. 0.10 norm. $\mathrm{NaOH}$ required to neutralize acidity of water extract of 10 grams compost.

† 0.2 per cent ammonium sulfate added.

\section{SULFATE FORMATION}

The production of water-soluble sulfates during the first weeks of incubation was very rapid in all mixtures. From the results recorded in table 3 it may be seen that after an incubation period of 15 weeks the inoculated mixtures had produced more sulfates than the uninoculted composts.

This gain, however, was largely lost after 18 weeks, due to the fact that the sulfate accumulation was slow between the 9th and 18th weeks of incubation. The reason for the slower accumulation may possibly be that the sulfates and free acid formed at first do not react with the mineral constituents present, or do so only very slightly, but when sufficient amounts are produced a comparatively rapid reaction takes place with the extremely small particles, while later on the slower reaction takes place with the more coarse material. In the course of this process a part of the sulfates unite with bases of the silicates and become insoluble in water. The more rapid attack of small particles would 
indicate that finely ground greensand yields greater amounts of the water soluble potassium. An experiment conducted with material of different fineness showed distinctly that the finer material used, the faster the reaction takes place. No attempt was made to study the possible interchange of bases in this relatively slow reaction process.

\section{WATER-SOLUBLE POTASSIUM}

Water-soluble potassium determinations were made at the beginning of the experiment, after $1,3,6,9,15$ and 18 weeks. The data secured after 18 weeks are recorded in table 3.

The increase in water-soluble potassium was gradual in all cultures. The amounts during the first 12 weeks were small.

Until the fifteenth week the inoculated cultures were ahead of the uninoculated, but after 18 weeks not much difference was apparent. The possible reason has been pointed out by the discussion of the accumulation of water soluble sulfates.

The total water-soluble potassium seemed to be greatest in all mixtures without soil additions, but if calculated on the basis of the per cent of total potassium present, this is reversed.

It is necessary that a certain degree of acidity be produced before the potassium becomes water-soluble. The amounts of sulfates formed do not necessarily have to reach a certain quantity, but the acidity produced has to be of a certain intensity. The point at which the potassium of the greensand becomes more rapidly water soluble lies between the $\mathrm{pH}$ values 2.7 and 2.3, as is shown by determination made from greensand extracts treated with dilute sulfuric acid. Nevertheless, the quantities of sulfates formed have a close relation to the intensity of the free acid formed.

The curves in figure 1, show clearly the relation between hydrogen-ion concentration, acidity accumulation, sulfate formation and water-soluble potassium in two of the inoculated mixtures.

It seems evident that a part of the acid or acid sulfates formed in culture 1 reacted with the soil constituents, while in culture 3 these sulfates or the free acid acted more directly upon the potassium of the greensand. It would seem that most rapid and thus most economical results would be obtained if a part of the composts were used for inoculaton of new compost mixtures, eliminating thereby the long period of incubation before a certain hydrogen-ion concentration and a certain acidity accumulation is reached.

As has been pointed out above, the total water-soluble potassium seemed to be greatest in all mixtures containing no soil, but from the data presented in table 4 it is evident that a smaller percentage of the total potassium present had been liberated in the cultures without additions of soil. It should be kept in mind that the greensand contained but 4.63 per cent of total potassium and much of the materials present react with the acid or acid compounds. formed. Besides, the reaction was not complete and still continuing at the end of 18 
weeks. Since only a small amount of the sulfur was oxidized it does not seem necessary to add such large quantities of sulfur as was done in this experiment. The cultures to which $\mathbf{4 0} \mathrm{gm}$. of sulfur were added had accumulated almost

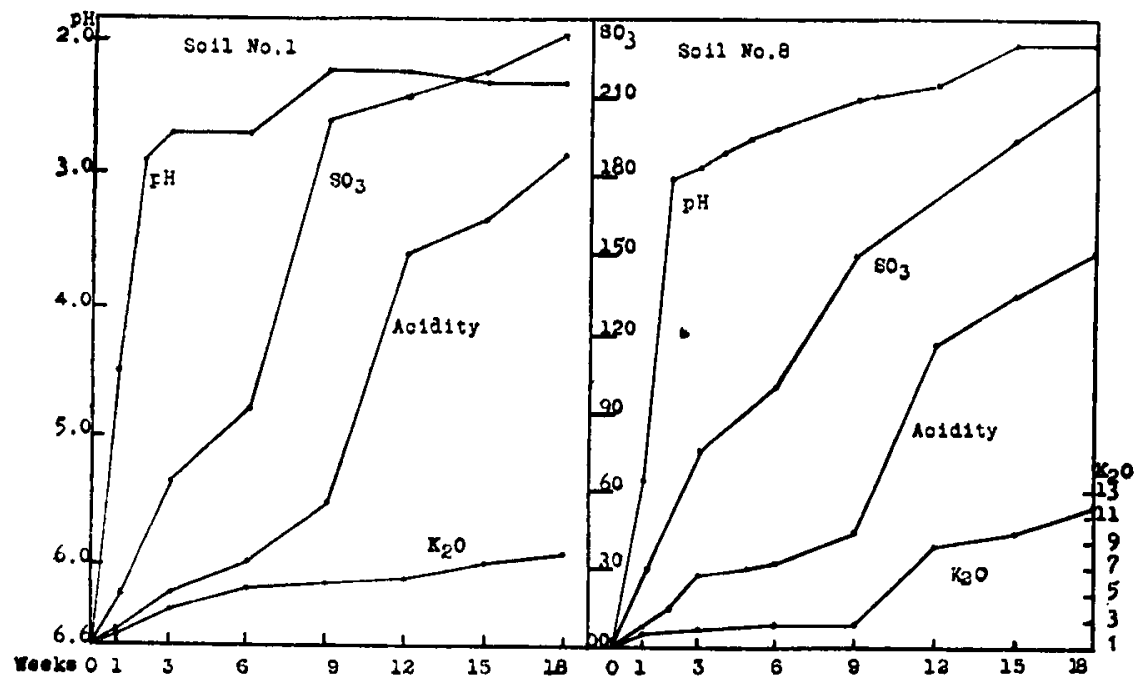

Fig. 1. Graphs Showing the Relation Between Hydrogen-Ion Concentration Sulpates, Acidity and Water Soluble Potassium in Compost Mixtures NUMBERS 1 AND 8

TABLE 4

Total sulfur oxidized and total water-soluble potassium obtained

\begin{tabular}{|c|c|c|c|c|c|c|}
\hline \multirow[t]{2}{*}{$\begin{array}{l}\text { COLIURE } \\
\text { NDKBTR }\end{array}$} & \multirow{2}{*}{$\begin{array}{c}\begin{array}{c}\text { SULFUR IN } \\
\text { MIXTURE }\end{array} \\
\mathrm{gm} .\end{array}$} & \multicolumn{2}{|c|}{ SULFUR OXIDIEED } & \multirow{2}{*}{$\begin{array}{c}\begin{array}{c}\text { POTASSIUM } \mathrm{K}_{8} \mathrm{O} \\
\text { IN NDTTURE }\end{array} \\
\mathrm{gm.}\end{array}$} & \multicolumn{2}{|c|}{ SOLUBLE POTASSIOX } \\
\hline & & $g m$. & per cent & & $g m$. & per cent \\
\hline 1 & 20 & 1.864 & 9.32 & 3.624 & 0.1582 & 4.37 \\
\hline 2 & 40 & 1.830 & 4.57 & 2.718 & 0.1478 & 5.44 \\
\hline 3 & 20 & 1.606 & 8.03 & 7.248 & 0.2358 & 3.26 \\
\hline 4 & 40 & 1.658 & 4.14 & 6.342 & 0.2536 & 3.99 \\
\hline 5 & 20 & 1.698 & 8.49 & 8.154 & 0.3296 & 4.04 \\
\hline 6 & 40 & 1.474 & 3.68 & 7.248 & 0.2294 & 3.17 \\
\hline 7 & 20 & 1.592 & 7.96 & 8.154 & 0.2542 & 3.12 \\
\hline 8 & 40 & 1.723 & 4.31 & 7.248 & 0.2342 & 3.23 \\
\hline 9 & 20 & 1.578 & 7.89 & 3.624 & 0.1446 & 3.92 \\
\hline 10 & 40 & 1.746 & 4.36 & 2.718 & 0.1214 & 4.47 \\
\hline 11 & 20 & 1.442 & 7.21 & 7.248 & 0.2214 & 3.07 \\
\hline 12 & 40 & 1.588 & 3.97 & 6.342 & 0.2262 & 3.57 \\
\hline 13 & 20 & 1.369 & 6.85 & 8.154 & 0.2454 & 3.01 \\
\hline 14 & 40 & 1.196 & 2.99 & 7.248 & 0.2262 & 3.13 \\
\hline 15 & 20 & 1.540 & 7.70 & 8.154 & 0.2760 & 3.38 \\
\hline 16 & 40 & 1.528 & 3.82 & 7.248 & 0.2435 & 3.36 \\
\hline 17 & None & & & 9.06 & 0.0007 & 0.078 \\
\hline 18 & None & & & 9.06 & 0.0006 & 0.067 \\
\hline
\end{tabular}


exactly the same amount of sulfates as the culture to which $20 \mathrm{gm}$. of sulfur were added. The relation between the percent of potassium liberated and the per cent of sulfur oxidized was roughly 1:2. It seems therefore, that approximately 10 per cent of sulfur of the total greensand is sufficient to secure satisfactory yields.

\section{SAND CULTURES}

The per cent of water-soluble potassium was low in all cases, but it seemed sufficient to supply plants with the necessary amounts of potassium. In order to test whether or not the available potassium would be sufficient to support plants with this necessary plant food element, pot cultures were conducted with soy bean plants. Since, as has been shown by earlier investigations, potassium absorption is greatest during the first part of the growing period of the plants, soy beans were grown for only 6 weeks. Soy bean plants ordinarily bloom in the greenhouse between the fourth and fifth week and the growing period of 6 weeks would be enough to test the value of the material for these plants.

Although it is known that the ordinary glazed earthenware pots furnish very small amounts of soluble impurities among which are potassium compounds, it was thought that the differences among the cultures would be large enough to give this test practical value. As a source of the necessary nutrient salts Shive's cultural solution $\mathrm{R}_{5} \mathrm{C}_{2}$ was used.

Each pot contained $5 \mathrm{kgm}$. washed quartz sand. Treatments, in triplicate series were as follows:

1. None

2. Dry greensand.

3. Shives cultural solution $\mathrm{R}_{5} \mathrm{C}_{2}$.

4. Composted greensand.

5. Shive's solution, except potassium, plus dry greensand.

6. Shive's solution, except potassium, plus composted greensand.

The greensand substituted for the potassium in Shive's cultural solution was calculated to be approximately that necessary to supply an amount of potassium equivalent to that in the solution. The inoculated greensand had been composted for a period of 18 weeks previous to the application. The results from the plants grown in these cultures would thus be comparable with the sults of the plants grown in cultures with the easily available potassium of Shive's cultural solution.

The soy bean seeds were selected for size and germinated in sand. The seedlings were then selected again to be as nearly alike as possible and planted when about two inches high. After the planting the cultures were inoculated with a few cc. of a water extract known to contain nodule forming bacteria. The yields obtained after a growing period of 6 weeks are presented in table 5 in the form of dry weights of tops, height of plants, number of pods produced, and the $\mathrm{pH}$ values at the beginning and at the end of the experiment. 
It will be noted that the dry greensand alone had some influence on the growth of these soy bean plants.

The dry greensand substituted for the potassium in the cultural solution was apparently not able to replace the potassium fully for the needs of these plants in this period of growth, but the composted greensand seemed to render suffcient potassium available for their needs. In fact, the cultures receiving greensand as a substitute matured earlier and seemed more vigorous than the plants in Shive's nutrient solution.

From the numbers of pods produced, it can be seen that the plants receiving greensand as a substitute for the potassium in Shive's solution would yield also more seeds, showing that their earlier maturity was profitable instead of detrimental, although slightly less hay was produced as compared with the plants grown in the $\mathrm{R}_{5} \mathrm{C}_{2}$ solution. In addition, more and larger nodules were noticed on the roots of all plants receiving potassium in the form of greensand.

TABLE 5

'Yields of tops of soy bears grown in sand cultures, with Shive's mutrient solution as a basis, with the potassium of the solution replaced by the potassium of composted greensand

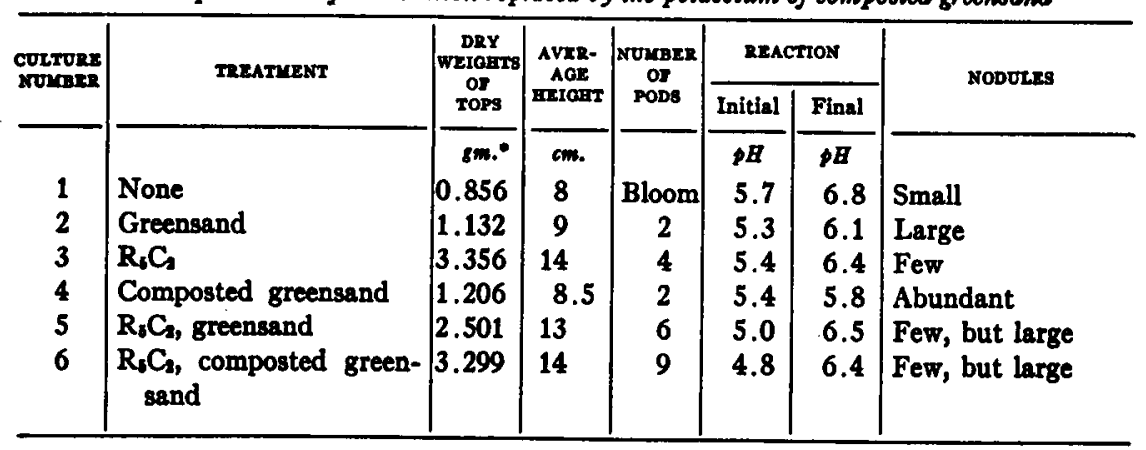

- All results given are averages of 3 cultures.

\section{CONCLUSIONS}

1. In composts consisting of greensand and sulfur, small amounts of potassium are liberated.

2. No great differences occured between inoculated and uninoculated sulfurgreensand mixtures, because there was contamination of the uninoculated mixtures.

3. The potassium of the greensand is made available at a certain hydrogenion concentration, lying between the $\mathrm{pH}$ values 2.7 and 2.3 .

4. There is a definite relation between the hydrogen-ion concentration and sulfate formation, and the water-soluble potassium.

5. Soy bean plants grown in quartz sand and with Shive's nutrient solution in which composted greensand was substituted for the potassium of the cultural solution are able to make as great a dry weight of tops as in similar cultures in which the potassium was supplied in the form of potassium phosphate. 
Soy bean plants receiving composted greensand as a source of potassium matured earlier and yielded more seeds than the plants grown in Shive's cultural solution.

\section{REFERENCES}

(1) Avess, J. W., AND Bortz, G. E. 1919 Effect of sulfofication and nitrification on potassium and other soil constituents. In Soil Sci., v. 7, p. 183-195.

(2) Asmiey, G. H. 1917 Notes on the greensand deposits of the Eastern United States. U. S. Geol. Sur. Bul. 660 B.

(3) BLARr, A. W. 1916 The agricultural value of greensand marl. In N. J. Agr. Exp. Sta. Cir. 61.

(4) Clark, B. W. 1893 A preliminary report on the Cretaceous and Tertiary formations of New Jersey. In N. J. Geol. Sur. Ann. Rpt. 1892, p. 169-239.

(5) Coox, G. H. 1868 Geology of New Jersey. State Geological Survey, New Bruntwick, N. J.

(6) Gordos, Tr. 1830 History and Gazeteer of New Jersey. (p. 442-443 in 15.)

(7) LIPMAN, J. G., AND BLAIR, A. W. 1917 Vegetation experiments on the availability of phosphorus and potassium compounds. In N. J. Agr. Exp. Sta. Ann. Rpt. 38, p. 353-368,

(8) Lipuan, J. G., Blatr, A. W., Martns, W. H., AND Beckwira, C. S. 1921 Inoculated sulfur as a plant-food solvent. In Soil Sci., v. 11, p. 87-92.

(9) McCarl, A. G., AND Sutra, A. M. 1920 Effect of manure-sulfur compost upon the availability of the potassium of greensand. In Jour. Agr. Res., v. 19, p. 239-256.

(10) Morsr, JrDmint 1819 American Universal Geography, 7th ed. Lincoln and Edmands, Boston and G. Clark, Charleston, Mass.

(11) Patrerson, H. J. 1906 Results of experiments on the liming of soils. Md. Agr. Exp. Sta. Bul. 110.

(12) Stybert, H. 1826 Analyses of the green earth from Rancocas creek, New Jersey. In Mem. Phila. Soc. Prom. Agr., v. 5, p. 18-46.

(13) Strevve, R. N. 1920 Potash recovery in New Jersey. In Chem. Age, v. 4, p. 69-73.

(14) TRUx, R., AND GEIss, F. W. 1918 Experiments on the value of greensand as a source of potassium for plant culture. In Jour. Agr. Res., v. 15, p. 483-492.

(15) VAN AISTINE, E. 1920 The determination of hydrogen-ion concentration by the colorimetric method and an apparatus for rapid and accurate work. In Soil Sci., v. 10, p. 467-479. 
PLATE 1

Soy Bran Plants Grown in Quartz Sand Treated as Follows

1. None.

4. $\mathrm{R}_{6} \mathrm{C}_{3}$.

10. Composted greensand.

11. Greensand.

12. $\mathrm{R}_{6} \mathrm{C}_{2}$ and composted greensand.

13. $R_{\mathbf{S}} C_{2}$ and greensand. 


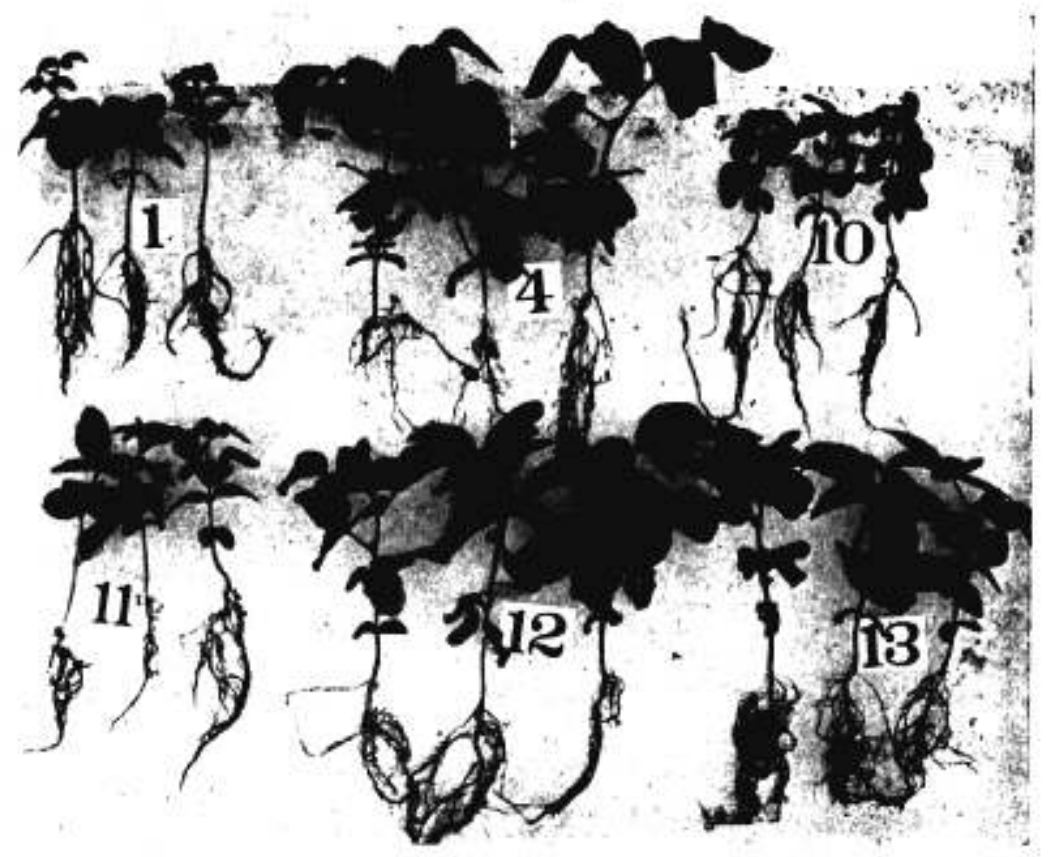

